\title{
Lactate-Mediated Protection of Retinal Ganglion Cells
}

Vohra, Rupali; Aldana, Blanca I.; Bulli, Giorgia; Skytt, Dorte M.; Waagepetersen, Helle; Bergersen, Linda H.; Kolko, Miriam

Published in:

Journal of Molecular Biology

DOI:

10.1016/j.jmb.2019.03.005

Publication date:

2019

Document version

Publisher's PDF, also known as Version of record

Document license:

Unspecified

Citation for published version (APA):

Vohra, R., Aldana, B. I., Bulli, G., Skytt, D. M., Waagepetersen, H., Bergersen, L. H., \& Kolko, M. (2019). Lactate-Mediated Protection of Retinal Ganglion Cells. Journal of Molecular Biology, 431(9), 1878-1888. https://doi.org/10.1016/j.jmb.2019.03.005 


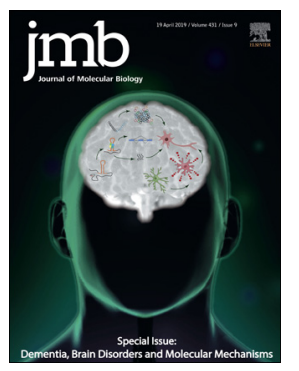

\title{
Lactate-Mediated Protection of Retinal Ganglion Cells
}

\author{
Rupali Vohra ${ }^{1}$, Blanca I. Aldana ${ }^{1}$, Giorgia Bulli ${ }^{1}$, Dorte M. Skytt ${ }^{1}$, \\ Helle Waagepetersen ${ }^{1}$, Linda H. Bergersen ${ }^{2,3}$ and Miriam Kolko ${ }^{1,4}$ \\ 1 - Department of Drug Design and Pharmacology, University of Copenhagen, Copenhagen, Denmark \\ 2 - Center of Healthy Aging, University of Copenhagen, Copenhagen, Denmark \\ 3 - Brain and Muscle Energy Group, Faculty of Dentistry, Institute of Oral Biology, University of Oslo, Oslo, Norway \\ 4 - Department of Ophthalmology, Rigshospitalet-Glostrup, Glostrup, Denmark
}

Correspondence to Miriam Kolko: University of Copenhagen, Rigshospitalet-Glostrup, Glostrup, Denmark. miriamk@sund.ku.dk

https://doi.org/10.1016/j.jmb.2019.03.005

Edited by Kristine Karla Freude

\begin{abstract}
Loss of retinal ganglion cells (RGCs) is a leading cause of blinding conditions. The purpose of this study was to evaluate the effect of extracellular L-lactate on RGC survival facilitated through lactate metabolism and ATP production. We identified lactate as a preferred energy substrate over glucose in murine RGCs and showed that lactate metabolism and consequently increased ATP production are crucial components in promoting RGC survival during energetic crisis. Lactate was released to the extracellular environment in the presence of glucose and detained intracellularly during glucose deprivation. Lactate uptake and metabolism was unaltered in the presence and absence of glucose. However, the ATP production declined significantly for $24 \mathrm{~h}$ of glucose deprivation and increased significantly in the presence of lactate. Finally, lactate exposure for 2 and $24 \mathrm{~h}$ resulted in increased RGC survival during glucose deprivation. In conclusion, the metabolic pathway of lactate in RGCs may be of great future interest to unravel potential pharmaceutical targets, ultimately leading to novel therapies in the prevention of blinding neurodegenerative diseases, for example, glaucoma.
\end{abstract}

(C) 2019 Elsevier Ltd. All rights reserved.

\section{Introduction}

Retinal ganglion cell (RGC) loss is a major cause of blinding inner retinal conditions, such as glaucoma. RGCs and their axons constitute the optic nerve and are crucial in transmitting neuronal signals from the eye to the brain to provide visual interpretation. Hence, compromised RGC survival subsequently results in progressing visual field loss and in advanced cases of blindness $[1,2]$. Thus, further understanding of RGC homeostasis is essential for the development of novel treatment strategies to prevent inner retinal neurodegenerative conditions.

The axons of RGCs are unmyelinated within the retina and therefore only protected by the surrounding macroglial cells, primarily the Müller cells. Therefore, it has been proposed that the glia-neuron partnership is important for RGC survival [3-5]. In line with this, Müller cells have been shown to secrete various neuroprotective factors, such as energy substrates, growth factors, neutrophins, and prostaglandins [4,6,7], which are known to further facilitate RGC survival. In addition, co-culture studies have identified that the mere presence of Müller cells is a fundamental factor for sustaining RGC survival [8-12]. Recent studies have identified lactate as a neuroprotective molecule. In this context, lactate has been shown to act as an essential energy fuel to maintain neuronal survival and functions [13-19]. Similar to these studies, we and others have recently discovered that Müller cells secrete lactate [20-23] and that extracellular lactate is an essential modulator of Müller cell survival and function [20]. Likewise, we suggest that extracellular lactate concentrations may be equally important for RGC survival.

In general, the retina is a highly metabolic organ with up to 10-fold higher concentrations of lactate (5- 
$50 \mathrm{mmol} / \mathrm{L}$ ) compared to other body tissues and blood [24-26]. Although lactate is primarily known to be produced during anaerobic conditions, retinal cells have also been shown to produce lactate during sufficient oxygen availability (the Warburg effect) $[21,27]$. In a recent study, we demonstrated that lactate was preferred over glucose in Müller cells as an energy source [20], thereby challenging the general assumption of lactate being merely a metabolic waste molecule. Moreover, neuroprotective responses to extracellular lactate have been reported in the brain concerning preservation of long-term memory [28] and protecting against traumatic brain injury $[29,30]$. The novel neuroprotective features of lactate in the brain are, however, still in the process of being unraveled, and we propose that similar beneficial features may also be identified in the retina.

In the present study, we aimed to investigate possible neuroprotective effects of extracellular lactate in primary murine RGC cultures and to establish whether lactate is metabolized, securing survival of the RGCs and thereby protecting the RGCs from a toxic insult mimicked by glucose deprivation.

\section{Materials and Methods}

\section{Cell cultures: Primary RGCs and Müller cells}

Murine RGCs and Müller cells were cultured from dissected retinas of neonatal mice (C57BL/6J, Charles River, Germany and/or Janvier, France) at postnatal days 7-8. The mice were euthanized by cervical dislocation, and the eyes were enucleated into D-PBS (cat. no. 14287080; Gibco). Retinas were dissected under a microscope (Leica S4E) using a forceps and curved scissor. The simultaneous purification of RGCs and Müller cells was obtained according to the method described by Skytt et al. [8]. In experiments where the Müller cells alone were purified, dissected retinas were incubated for 30 min in DMEM (21885025; Gibco) supplemented with collagenase $(65 \mathrm{U} / \mathrm{mL})$ and trypsin $(0.25 \%)$. The cells were after incubation rinsed thrice in DMEM containing $10 \%$ fetal bovine serum (10270-106; Gibco) to terminate the digestion. The digested retinas were mechanically dissociated by gentle trituration through an 18-G needle producing a suspension of tissue micro-aggregates and single cells. Cells were seeded in tissue culture plates (TPP) at a density of $0.7-1$ retina $/ \mathrm{cm}^{2}$. Müller cells were maintained at $37^{\circ} \mathrm{C}$ in a humidified atmosphere with $5 \% \mathrm{CO}_{2}$ and cultured in DMEM containing glucose $(1.0 \mathrm{~g} / \mathrm{L})$, pyruvate (1 $\mathrm{mM})$, L-alanyl-glutamine (3.97 mM), supplemented with penicillin $(90$ units $/ \mathrm{mL})$ and streptomycin $(90 \mu \mathrm{g} /$ $\mathrm{mL}$ ), and $10 \%$ fetal bovine serum. Two days after purification, the plates were washed vigorously with media to detach tissue aggregates and non-adherent cells. The cells were kept in culture for 7-14 days with culture medium changed twice a week. Aggregates and debris were removed by forcible resuspension of medium onto the cell monolayer. Cell cultures of Müller cells were approximately $80 \%-90 \%$ confluent when used for experiments.

RGCs were kept in culture in a $37{ }^{\circ} \mathrm{C}$ humidified atmosphere with $10 \% \mathrm{CO}_{2}$ for 7 days in a ND-growth medium with change of one third of the medium volume on the third day in culture and 1 day prior to experiments. The RGCs were seeded in TPP plates at a density of 150,000 cells $/ \mathrm{cm}^{2}$. The ND-growth culture medium was formulated as described by Skytt el al. [8]. Briefly, neurobasal medium (cat. no. 12349015; Gibco) was mixed in equal amounts with DMEM high-glucose medium consisting of $25 \mathrm{mM}$ glucose (31966047; Gibco) with the addition of penicillin (1000 units $/ \mathrm{mL})$, streptomycin $(1000 \mu \mathrm{g} / \mathrm{mL})$, insulin $(0.5 \mu \mathrm{g} / \mathrm{mL})$, sodium pyruvate $(1.5 \mathrm{mM}), 3,3,5-$ Triiodo-L-thyronine $(40 \mathrm{ng} / \mathrm{mL})$, L-glutamine $(3.7 \mathrm{mM})$, B27 supplement (1x; Gibco), and trace elements B (1x; Cellgro, USA). The medium was also supplemented with a Sato stock consisting of transferrin (to reach $100 \mu \mathrm{g} / \mathrm{mL}$ in media), BSA (to reach $100 \mu \mathrm{g} / \mathrm{mL}$ in media), progesterone (to reach $63 \mathrm{ng} / \mathrm{mL}$ in media), putrescine (to reach $16 \mu \mathrm{g} / \mathrm{mL}$ in media), and sodium selenite (to reach $40 \mu \mathrm{g} / \mathrm{mL}$ in media). In addition, NAC $(5 \mu \mathrm{g} / \mathrm{mL})$, biotin $(10 \mathrm{ng} / \mathrm{mL})$, BDNF $(50 \mathrm{ng} / \mathrm{mL}, 248-$ BD-025; R\&D Systems, UK), CNTF (10 ng/mL, 257NT-010; R\&D Systems), FGFb (10 ng/mL, PMG0034; Gibco), and forskolin $(4,2 \mu \mathrm{g} / \mathrm{mL})$ were added to the medium. For treatment, neurobasal (0050128DJ; Gibco) and DMEM without glucose (A14430; Gibco) were used for glucose deprivation and in experiments with $6 \mathrm{mM}$ glucose, a stock solution of $2.5 \mathrm{M}$ glucose was used to obtain the desired concentration of $6 \mathrm{mM}$ glucose. The specific concentration of $6 \mathrm{mM}$ of glucose was chosen to represent physiological systemic concentrations of glucose in humans.

\section{Retinal explant cultures}

Eyes were removed immediately postmortem from 8 to 10 weeks old $\mathrm{C} 57 \mathrm{BI} / 6 \mathrm{~J}$ mice (Janvier, France). Whole tissue retinas were taken out in one piece by using a needle to punctuate the eye and a curved scissor to remove the anterior part of the eye. Two forceps were used to detach the sclera of the remaining part of the eye, and fine brushes were used to gently move the explant if needed as described previously $[31,32]$. The retinas were oriented with the ganglion cell layer facing upward. One retina was acknowledged as a biological sample and divided into four retinal explants, which accounted for a specific time point. Retinal explants were cultured directly in cell culture inserts in TPP plates and treated with control media ( $6 \mathrm{mM}$ glucose) and treatment media (0 $\mathrm{mM}$ glucose) at day 0 (day of setup). The explants were subsequently cultured for $2 \mathrm{~h}, 24 \mathrm{~h}, 3$ days, and 7 days in a humidified incubator with $5 \% \mathrm{CO}_{2}$ at $37^{\circ} \mathrm{C}$. 


\section{Lactate assay}

RGCs, Müller cells, and retinal explants were treated with medium (DMEM A1443001 for Müller cells, neurobasal 0050128DJ for retinal explants) containing $6 \mathrm{mM}$ glucose or $0 \mathrm{mM}$ glucose for 2 and $24 \mathrm{~h}$ at $37^{\circ} \mathrm{C}$ in respectively $10 \% \mathrm{CO}_{2}$ for $\mathrm{RGCs}$ and $5 \% \mathrm{CO}_{2}$ for Müller cells and retinal explants. The retinal explants were additionally treated for 3 and 7 days. The media was collected and kept at $-80^{\circ} \mathrm{C}$ until measurements were performed. The lactate measurements were determined by colorimetric detection employing a Lactate Assay Kit (SigmaAldrich, MAK064-1KT) according to the manufacture's protocol and absorbances were read at $570 \mathrm{~nm}$.

\section{Lactate dehydrogenase assay}

Lactate dehydrogenase (LDH) cell viability kit (Takara Bio, Inc., Shiga, Japan) was used to quantitatively assess retinal tissue viability. Retinal explants were treated according to previous described treatments for 2 h, 24 h, 3 days, and 7 days. The media was collected and LDH release was determined as measurement for viability by the absorbance readings at $490 \mathrm{~nm}$. Tissue viability was calculated based on the absorbance readings of the collected media.

\section{Metabolic labeling studies}

Cell culture medium was changed 1 day prior to the experiments. To examine lactate metabolism in the primary mice RGCs, the cells were incubated for $2 \mathrm{~h}$ at $37^{\circ} \mathrm{C}$ in DMEM in the presence $(6 \mathrm{mM})$ or absence $(0 \mathrm{mM})$ of unlabeled D-glucose. At the start of treatment (time $=0 \mathrm{~h}$ ), the cells were spiked with an aliquot of sodium L-[U- $\left.{ }^{13} \mathrm{C}\right]$-lactate $(98 \%$ $\left[{ }^{13} \mathrm{C}\right]$ enriched; CLM-1579-PK; Cambridge Isotopes Laboratories Inc., MA, USA) to a final concentration of $10 \mathrm{mM}$. To investigate the metabolism of glucose in comparison with lactate, treatment with $6 \mathrm{mM}$ labeled D-glucose (D-[ $\left.{ }^{13} \mathrm{C}\right]$-glucose $(99 \%)\left[{ }^{13} \mathrm{C}\right]$ enriched; CLM-1396-10; Cambridge Isotopes Laboratories Inc., MA, USA), with and without spiking of unlabeled sodium L-lactate to a final concentration of $10 \mathrm{mM}$, was performed. After the 2-h treatment, the medium was collected and cells were rinsed twice with ice-cold phosphate-buffered saline. Subsequently, RGCs were extracted in $70 \%$ ethanol and centrifuged $\left(20,000 \mathrm{~g}\right.$ for $20 \mathrm{~min}$ at $\left.4{ }^{\circ} \mathrm{C}\right)$ to separate the soluble extract (supernatant) from insoluble components (pellet). Protein content was determined in the pellets via the BCA protein assay kit (SigmaAldrich, USA). Media and cell extracts were both lyophilized and reconstituted in water for further biochemical analysis by gas chromatography coupled to mass spectrometry. Spectrometric anal- ysis was performed as previously described [33]. Briefly, extract samples were adjusted to $\mathrm{pH} 1-2$ with $\mathrm{HCl}$ and evaporated to dryness under nitrogen flow. Analytes were extracted into an organic phase (96\% ethanol/benzene) followed by derivatization with $14 \%$ DMF/86\% MTBSTFA with a modified procedure from Mawhinney et al. [34]. Standards containing unlabeled metabolites of interest and cell extracts were separated and analyzed in a gas chromatograph (Agilent Technologies 7820A chromatograph, J\&W GC column HP-5MS, parts no. 19091S-433) coupled to a mass spectrometer (Agilent Technologies, 5977E). The isotopic enrichment of the metabolites of interest was corrected for natural abundance of ${ }^{13} \mathrm{C}$ using the unlabeled standards and calculated according to Biemann [35]. Data are presented as labeling (\%) of $M+X$, where $M$ is the mass of the unlabeled molecule and $X$ is the number of labeled $\mathrm{C}$ atoms in a given metabolite.

\section{ATP assay}

Primary murine RGCs were treated for 2 and $24 \mathrm{~h}$ in the presence and absence of $6 \mathrm{mM}$ glucose with the addition of $10 \mathrm{mM}$ L-lactate. Intracellular ATP concentrations were measured using the Bioluminescent Somatic Cell Assay Kit (FLASC-1KT; Sigma-Aldrich) according to the manufacturer's protocol. A luminescence counter (Spectramax; Molecular Devices) was used to measure the luminescence signal from the samples added in black 96-well plates. Adenosine 5'-triphosphate standards were used to create an ATP calibration curve for the assay. ATP amounts were calculated using the standard and corrected for amount of protein, which was determined by the BCA protein assay kit (Sigma-Aldrich).

\section{MTT viability assay}

Müller cell survival was determined by the colorimetric method, MTT (3-(4,5-dimethyl-2-thiazolyl)2,5-diphenyl-2H-tetrazolium bromide), measuring the ability of viable cells to reduce MTT measured at the absorbance $560 \mathrm{~nm}$. The RGC cultures were incubated in medium with the presence or absence of glucose and/or L-lactate for 2 and $24 \mathrm{~h}$. Subsequently, the cells were incubated with $12 \mathrm{mM} \mathrm{MTT}$ solution for $1 \mathrm{~h}$ at $37^{\circ} \mathrm{C}$ and the cells were solubilized in $10 \%$ SDS and $0.01 \mathrm{M} \mathrm{HCl}$. Eighteen hours later, the absorbance was measured at $560 \mathrm{~nm}$. The background readings (blank wells with medium, MTT solution, and solubilization buffer) were subtracted from the absorbance readings of the treated wells to obtain an adjusted absorbance reading representing cell viability. Finally, the readings were divided by the adjusted absorbance readings of untreated (control) cells to obtain a percentage of cell survival. 


\section{Statistics}

Data were analyzed using GraphPad software (GraphPad Prism version 7.0). Statistical comparisons between two groups were analyzed by unpaired twotailed $t$ test. Statistical comparisons between several groups were analyzed by one-way ANOVA followed by Tukey's multiple comparison post-test. Survival data were analyzed using two-way ANOVA (Tukey's multiple comparisons post hoc test). In all analyses, $p<0.05$ were considered to be statistically significant. Both biological and technical replicates were used to enable sufficient statistics. "Biological replicates" indicate a pool of biologically different retinas, which were used to make the final Müller cell and RGC purification for one given experiment. Technical replicates indicate the amount of times a given measurement was performed.

\section{Results}

\section{Primary Müller cells and RGCs release lactate to the extracellular environment}

Extracellular lactate was quantified in treatment media (initially lactate free) after 2 and $24 \mathrm{~h}$ of treatment with $6 \mathrm{mM}$ glucose and $0 \mathrm{mM}$ glucose.

In Müller cells, extracellular lactate levels decreased from $7.9 \pm 1.5$ to $0.9 \pm 0.04 \mathrm{nmol} / \mu \mathrm{L}$ during glucose deprivation for $2 \mathrm{~h}(p<0.05)$. The same phenomenon was established after $24 \mathrm{~h}$ of glucose deprivation, where lactate release decreased from $54.7 \pm 1.7$ to $1.1 \pm 0.04 \mathrm{nmol} / \mu \mathrm{L}(p<0.0001)$. In the presence of $6 \mathrm{mM}$ extracellular glucose, lactate release from Müller cells increased significantly over time from 2 and $24 \mathrm{~h}$ $(p<0.0001)$ (Fig. 1a). The same was seen for RGCs, where lactate release increased from $6.9 \pm 2.4$ to $57.7 \pm 6.8 \mathrm{nmol} / \mathrm{\mu L}(p<0.0001)$ from 2 and $24 \mathrm{~h}$. When RGCs were deprived of glucose for $24 \mathrm{~h}$, lactate release from the RGCs decreased to $19.3 \pm 2.3 \mathrm{nmol} /$ $\mu \mathrm{L}(p<0.001)$ (Fig. 1b). In retinal explants, lactate release increased over time when the explants were supplemented with glucose. Glucose-deprived explants did not release any significant levels of lactate (Fig. 1c). Time-dependent retinal degeneration was confirmed through a commercialized viability assay (LDH assay). Glucose deprivation for $24 \mathrm{~h}$ and 3 days accentuated the time-dependent decrease in retinal viability to $5.1 \% \pm 0.8 \%$ and $5.2 \% \pm 1.6 \%$, respectively $(p<0.05)$ (Fig. 1d).

\section{Lactate is taken up and metabolized by RGCs}

To establish whether lactate was metabolized in RGCs, incubations with labeled [U- $\left.{ }^{13} \mathrm{C}\right]$-lactate were performed and compared with the metabolism of labeled [U- $\left.{ }^{13} \mathrm{C}\right]$-glucose.
Metabolism was measured by incorporation of carbon into various metabolic intermediates. The incorporation of ${ }^{13} \mathrm{C}$ from $\left[\mathrm{U}-{ }^{13} \mathrm{C}\right.$ ] glucose in to lactate $(p<0.05)$, alanine $(p<0.05)$, alpha-ketoglutarate $(p<0.05)$, aspartate $(p<0.05)$, glutamate $(p<0.05)$, succinate $(p<0.05)$, malate $(p<0.05)$, and fumarate decreased during simultaneous addition of $10 \mathrm{mM}$ of unlabeled lactate compared to treatment with $\left[\mathrm{U}-{ }^{13} \mathrm{C}\right]$ glucose alone (Fig. $2 \mathrm{a}-\mathrm{C}$ ). Incorporation of ${ }^{13} \mathrm{C}$ from $\left[\mathrm{U}-{ }^{13} \mathrm{C}\right]$ lactate remained unaltered by the addition of unlabeled glucose (Fig. 2d-f).

\section{Lactate metabolism increases ATP production in RGCs}

To correlate the effect of lactate metabolism in RGCs with the energy status of the cell, total ATP levels were measured. ATP levels remained stable within $2 \mathrm{~h}$ of treatment with lactate in glucose supplemented RGCs and glucose-deprived RGCs (Fig. 3a-c). Furthermore, glucose deprivation in itself did not have an effect of the total amount of ATP within $2 \mathrm{~h}$, whereas after $24 \mathrm{~h}$, total ATP levels decreased significantly to $81 \% \pm 4 \%$ $(p<0.01)$ (Fig. 3d). No changes of total ATP were seen in response to the addition of lactate in glucose supplemented RGCs (Fig. 3e).

The presence of $10 \mathrm{mM}$ of lactate for $24 \mathrm{~h}$ of glucose deprivation increased total ATP levels to $148 \% \pm 18 \%(p<0.05)$ (Fig. 3f).

\section{The presence of extracellular lactate increases survival of glucose-deprived RGCs}

RGC viability was determined to investigate the effect of lactate metabolism and increased ATP on overall survival of RGCs. Cell viability remained unaffected in glucose supplemented RGCs within 2 and $24 \mathrm{~h}$ of treatment with 10 and 20 mM L-lactate (Fig. $4 a$ and b). In glucose-deprived RGCs, however, the presence of $10 \mathrm{mM}$ of extracellular L-lactate increased survival from $71 \%$ to $96 \%$ after 2 h $(p<0.01)$ and from $55 \%$ to $72 \%$ after $24 \mathrm{~h}(p<0.01)$ (Fig. $4 \mathrm{a}$ and b). The presence of $20 \mathrm{mM}$ of extracellular L-lactate increased survival to $97 \%$ after 2 h $(p<0.01)$ (Fig. 4a).

Glucose deprivation in itself decreased RGC viability within 2 and $24 \mathrm{~h}$ to $71 \%(p<0.01)$ and $55 \%$ $(p<0.001)$, respectively. This effect was, however, abolished through the addition of 10 and $20 \mathrm{mM} \mathrm{L-}$ lactate after both 2 and $24 \mathrm{~h}$.

\section{Discussion}

Promoting RGC survival is pivotal in preventing blinding inner retinal neurodegenerative diseases. The aim of this study was to elucidate the potential role of lactate in RGC survival. We showed that lactate is released from isolated murine Müller cells and that extracellular lactate is taken up by RGCs to 
(a)

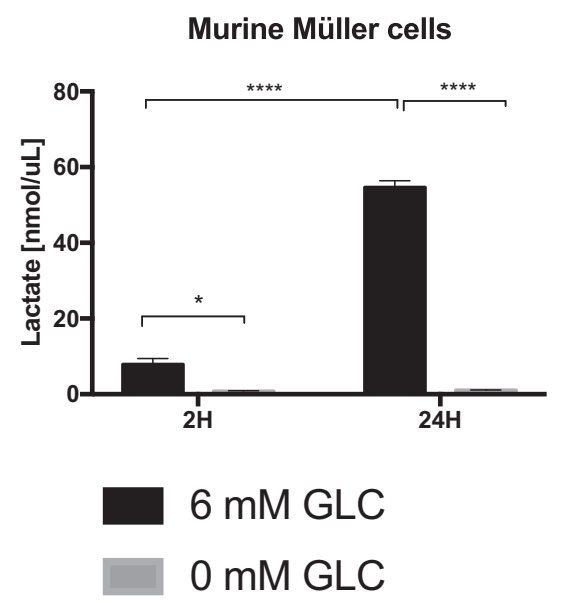

(c)

Murine Retinal Explants

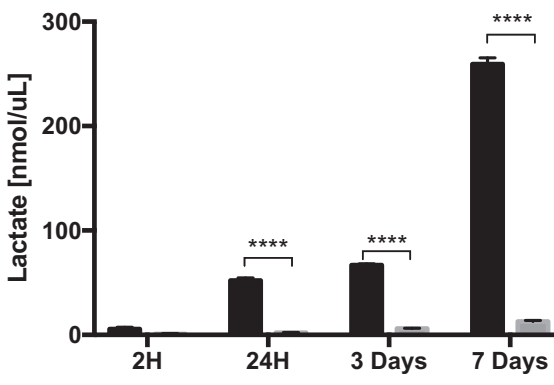

$6 \mathrm{mM}$ GLC

0 mM GLC (b)

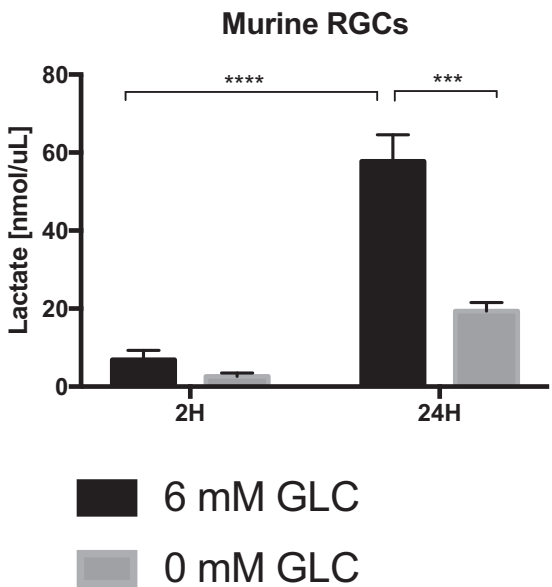

(d)

Murine Retinal Explants

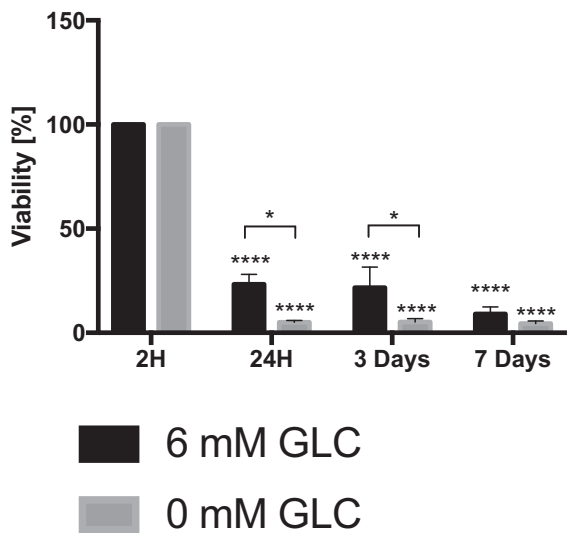

Fig. 1. Lactate release in murine Müller cells (a), RGCs (b), and retinal explants (c). Cells were treated with and without 6 mM glucose for 2 and $24 \mathrm{~h}$ for cells, and additionally 3 days and 7 days for retinal explants. In the presence of glucose, lactate release increased over time in both Müller cells and RGCs, as well as retinal explants. During glucose deprivation, lactate release decreased in both Müller cells and RGCs, as well as retinal explants. Furthermore, glucose deprivation accentuated retinal degeneration over time (d). Stars above columns indicate comparison to controls, respectively, "6 mM GLC" and " $0 \mathrm{mM}$ GLC". Data are presented as mean $\mathrm{nmol} / \mathrm{\mu L}$ lactate \pm S.E.M $(\mathrm{a}-\mathrm{c})$ and mean percentage $(\mathrm{d})$ of three biological replicates. ${ }^{\star} p<0.05,{ }^{\star \star \star} p<0.001,{ }^{\star \star \star \star} p<0.0001$. Statistics: two-way ANOVA (Tukey's multiple comparisons test).

secure survival of the cells during normal physiological conditions and to aid in neuroprotection of the RGCs during pathophysiological conditions, such as glucose deprivation. Overall, our study revealed novel features of lactate. Lactate was shown to be a preferred energy substrate compared with glucose, and the metabolism of lactate resulted in increased ATP production and survival of RGCs.

Generally, it is acknowledged that during sufficient oxygen and glucose supply, neuronal glucose metabolism will favor oxidative phosphorylation for energy
(ATP) production. However, retinal cells, including retinal neurons, are known to be primarily glycolytic $[21,22,27,36-39]$. Recently, Lindsay et al. [40] proposed that murine Müller cells display pyruvate kinase (PK) deficiency by expressing limited PK isoforms, indicating that the conversion of pyruvate from phosphoenolpyruvate, and ultimately lactate production in Müller cells, is limited. In opposition to this, we established that murine Müller cells were able to produce and release lactate in abundant and physiologically relevant amounts. Moreover, we also 
confirmed this previously by measuring increased extracellular lactate levels and an increase in the extracellular acidification rate during satisfactory glucose supply for $24 \mathrm{~h}$ in a human Müller cell line, MIOM1 cells, supporting the assumption of preferred glycolysis in Müller cells [41]. Thus, although the expression of PK might be limited, the activity of the enzyme in Müller cells seems to be intact. Nevertheless, during insufficient glucose supply, the Müller cells will shift to oxidative phosphorylation [42], and the Crabtree effect [43]. This effect is commonly seen in cancer cells and resembles metabolic effects of modified cell lines, such as the human Müller cell line, MIO-M1 [41]. To investigate the shift from glycolysis to oxidative phosphorylation in primary cells without genetic manipulation, the present study used isolated primary murine Müller cells as well as primary RGC cultures and found similar results where lactate was increasingly released to the extracellular environment during sufficient glucose supply, yet constrained during glucose deprivation. In support of our findings, a previous study performed on the RGC- 5 cell line, also revealed a net production of lactate during physiological glucose concentrations [21]. (a)

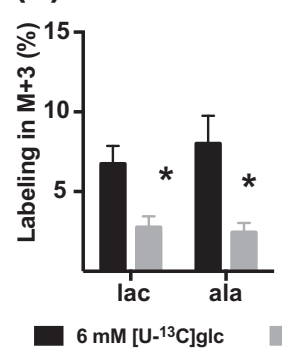

(d)

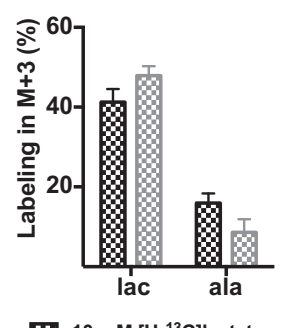

$10 \mathrm{mM}\left[\mathrm{U}-{ }^{13} \mathrm{C}\right]$ lactate (b)

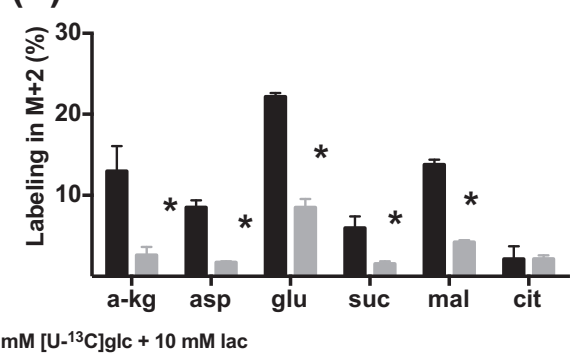

(e)

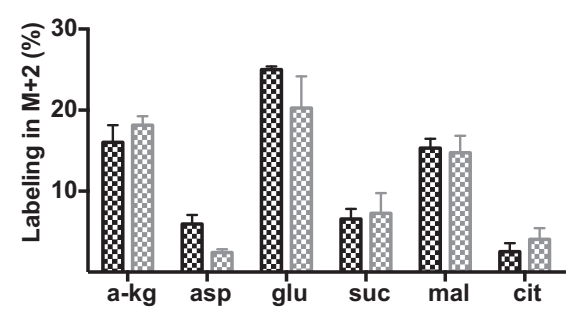

6. $10 \mathrm{mM}\left[\mathrm{U}-{ }^{13} \mathrm{C}\right]$ lactate $+6 \mathrm{mM}$ glucose (c)

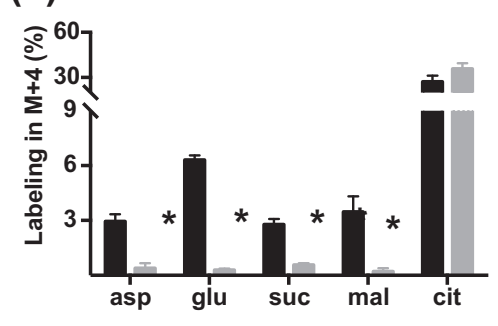

(f)

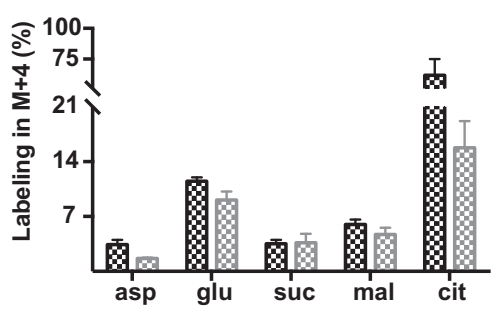

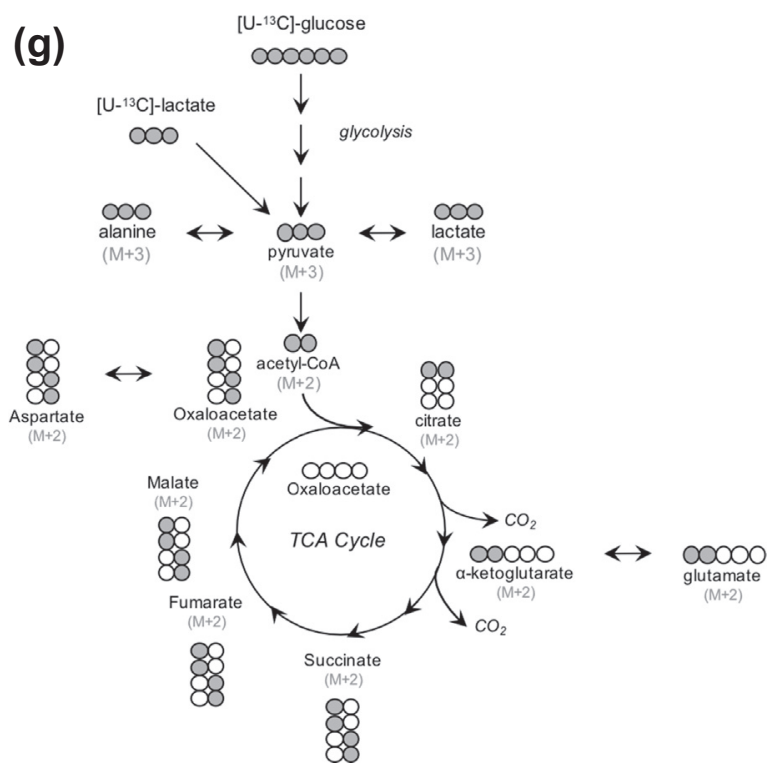

Fig. 2 (legend on next page) 
(a)

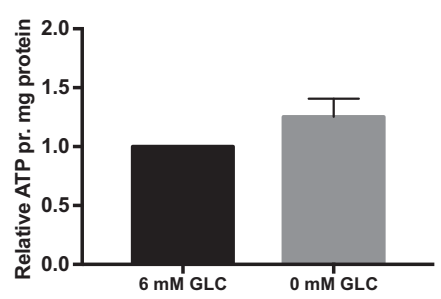

(d)

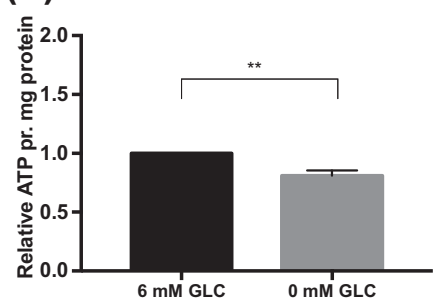

(b)

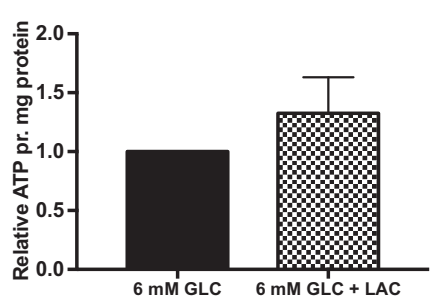

(e)

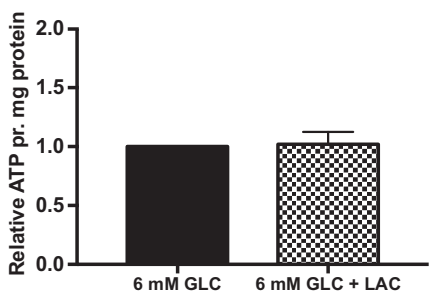

(c)

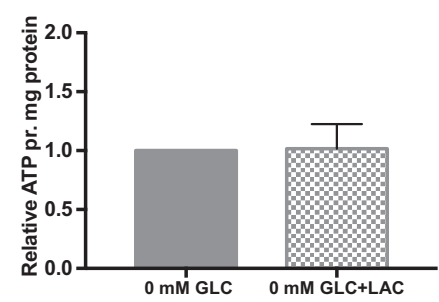

(f)

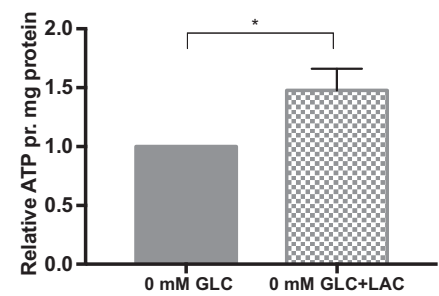

Fig. 3. ATP levels decrease in RGCs for $24 \mathrm{~h}$ of glucose deprivation and increase in response to addition of $10 \mathrm{mM}$ of Llactate. The cells were treated with and without $6 \mathrm{mM}$ glucose combined with $10 \mathrm{mM}$ of L-lactate (LAC) in the media for $2 \mathrm{~h}$ $(\mathrm{a}-\mathrm{c})$ and $24 \mathrm{~h}(\mathrm{~d}-\mathrm{f})$. ATP amounts were quantified by a commercial ATP kit (Sigma-Aldrich). No significant differences of ATP levels were seen within $2 \mathrm{~h}$. During glucose deprivation for $24 \mathrm{~h}$, ATP levels decreased significantly, while ATP levels increased significantly in the presence of lactate. Data are presented as mean relative ATP per mg of protein \pm S.E.M of five biological replicates with 3-9 technical replicates. ${ }^{*} p<0.05,{ }^{\star * *} p<0.001,{ }^{* * * *} p<0.0001$. Statistics: unpaired $t$ test.

Taken together, these findings combined with the verified expression of the lactate transporters, monocarboxylate transporters 1 and 4 in the inner retina [44] could imply the presence of a potential lactate-shuttle from Müller cells to RGCs and vice versa. Future studies comprising Müller cell-RGC co-cultures combined with monocarboxylate transporter blockage will be able to confirm this. The aspect of lactate shuttling between glia cells and neurons has previously been described as the lactate shuttle hypothesis presented by Pellerin and Magistretti et al. [45-47]. The hypothesis postulates that neurons are predominantly oxidative and astrocytes are mainly glycolytic, corresponding with reported elevated amounts of mitochondria in RGCs [48] and our previous findings regarding Müller cells [41]. The purpose of lactate-shuttle in the retina would be to ensure optimal levels of retinal lactate to avoid lactate acidosis, yet still maintain retinal structure and function. This has previously been investigated in single cells of the retina, namely, Müller

Fig. 2. $\left[\mathrm{U}-{ }^{13} \mathrm{C}\right]$-glucose and $\left[\mathrm{U}-{ }^{13} \mathrm{C}\right]$-lactate metabolism in RGCs. The cells were treated with $\left[\mathrm{U}-{ }^{13} \mathrm{C}\right]-\mathrm{glucose}(\mathrm{a}-\mathrm{C})$ and $\left[\mathrm{U}-{ }^{13} \mathrm{C}\right]$-lactate $(\mathrm{d}-\mathrm{f})$ for $2 \mathrm{~h}$. At the end of treatment, cell extracts were collected and analyzed using gas chromatography coupled to mass spectrometry for determination of the percentage distribution of ${ }^{13} \mathrm{C}$-labeled metabolites presented by ${ }^{13} \mathrm{C}$ labeling in $\mathrm{M}+3$ for lactate and alanine $(\mathrm{a}+\mathrm{d})$, in $\mathrm{M}+2$ for metabolites obtained after a first run of the TCA cycle $(b+e)$, as well as in the subsequent turn of the TCA cycle, $M+4(c+f)$. The incorporation of carbon in intermediate substrates of glycolysis and TCA cycle decreased in the presence of labeled $\left[\mathrm{U}-{ }^{13} \mathrm{C}\right]$-glucose combined with unlabeled lactate compared to the presence of $\left[\mathrm{U}-{ }^{13} \mathrm{C}\right]$-glucose alone. The incorporation of carbon from $\left[\mathrm{U}-{ }^{13} \mathrm{C}\right]$-lactate remained stable despite the addition of unlabeled glucose. This indicated that lactate may be preferentially metabolized over glucose. Panel g provides a metabolic overview of labeling patterns and metabolism. Glucose and lactate are metabolized to pyruvate, which enters the mitochondria. Pyruvate is further converted into acetyl-coA, which combined with unlabeled oxaloacetate yields citrate. White circles depict the mass $(\mathrm{M})$ of the unlabeled molecule, and X is the number of labeled $\mathrm{C}$ atoms in a metabolite. Measurement was performed on alpha-ketoglutarate, glutamate, succinate, malate, and aspartate for $M+2$ and $M+4$, indicating the first and second turns of the TCA cycle, respectively. $M+3$ indicates glycolytic metabolism or direct formation of pyruvate from $\left[\mathrm{U}-{ }^{13} \mathrm{C}\right]$-lactate. During experiments, only one labeled substrate was used at a time to distinguish between the metabolism of either glucose or lactate. Data are presented as labeling (\%) of $M+X$, where $M$ equals the mass of the unlabeled molecule and $X$ is the number of labeled $\mathrm{C}$-atoms in a metabolite. Lac, lactate; ala, alanine; $\alpha-\mathrm{kg}$, alpha-ketoglutarate; asp, aspartate; glu, glutamate; suc, succinate; mal, malate; fum, fumarate. Data are presented as mean \pm S.E.M of four biological replicates. ${ }^{\star} p<0.05$. Statistics: unpaired $t$ test. 
(a)

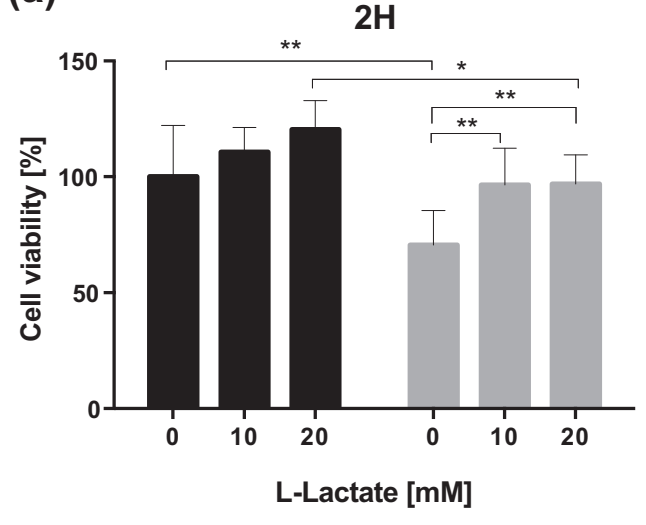

$6 \mathrm{mM}$ GLC

$0 \mathrm{mM}$ GLC (b)

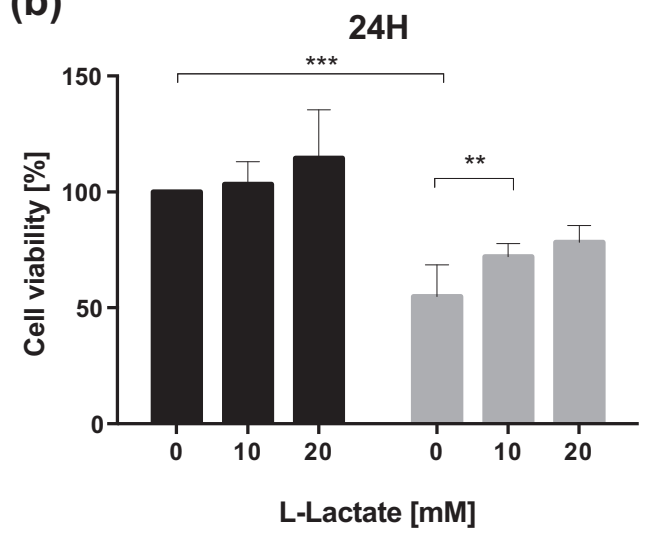

$6 \mathrm{mM}$ GLC

$0 \mathrm{mM}$ GLC

Fig. 4. Survival of glucose-deprived RGCs increases in response to lactate after both 2 and $24 \mathrm{~h}$ of treatment. The cells were treated with and without $6 \mathrm{mM}$ glucose combined with 10 and $20 \mathrm{mM}$ of L-lactate in the media for 2 and $24 \mathrm{~h}$. An MTT assay was performed to assess survival. After $2 \mathrm{~h}$, the presence of 10 and $20 \mathrm{mM}$ of L-lactate increased survival of the glucose-deprived RGCs significantly (a). During glucose deprivation for $24 \mathrm{~h}$, the presence of $10 \mathrm{mM}$ of L-lactate increased survival of the glucose-deprived RGCs significantly (b). No significant differences of survival were seen in glucose supplemented RGCs. Data are presented as mean percentage of cell viability \pm S.E.M of 6-7 biological replicates with four technical replicates. ${ }^{*} p<0.05,{ }^{* \star *} p<0.001,{ }^{\star * * *} p<0.0001$. Statistics: two-way ANOVA (Tukey's multiple comparisons test).

cells [20]. However, to our knowledge, this has not been shown in retinal tissue; thus, we measured total lactate release from retinal explants in response to glucose deprivation and revealed that lactate release was limited. This could imply that the tissue utilizes internal energy sources and does not have any excess metabolic substrates to generate and/or secrete lactate from. The strength of this model system reflects the use of adult mice compared to pubs utilized in the isolated cell cultures. A future perspective would be to use even older mice to mimic age-related retinal degeneration more thoroughly. Regardless, our study does confirm time-dependent degeneration of retinal explants from 8- to 10-week-old mice. During intact levels of extracellular glucose, lactate release from retinal explants increased over time. This may potentially aid in facilitating viability of the tissue explant in spite of time-dependent retinal degeneration. Although it is evident that the explants degenerate over time, independently of glucose availability, glucose deprivation accelerates this process compared to glucose-supplemented retinal explants. In the end, a compensatory increase in lactate production may, however, also be toxic by altering $\mathrm{pH}$. Thus, a tight regulation of extracellular lactate levels is required and may be obtained through lactate shuttle. The glialneuronal lactate shuttle hypothesis is an ongoing debate $[47,49]$, and the present study has added more information to this discussion. While the most widespread belief has been that glucose is predominantly metabolized in neurons [49], our study has shed light on the possible preference of lactate as an energy substrate for RGCs-at least in vitro. Thus, the lactate shuttle in the inner retina may involve a shuttle of lactate from Müller cells to fuel the RGCs, especially during critical conditions such as sparse glucose supply. Our viability studies performed on isolated RGCs confirm this protective effect of extracellular lactate on RGC survival during glucose deprivation. Hence, no significant difference in survival was established when comparing $6 \mathrm{mM}$ glucose supplemented RGCs with lactate-added glucose-deprived RGCs.

Interestingly, during glucose deprivation, the concentrations of released lactate from RGCs were still relatively high of approximately $17 \mathrm{nmol} / \mathrm{hL}$, indicating that RGCs may also utilize other metabolic pathways or other metabolic substrates as energy source. The neurobasal medium used in this study contain numerous branch-chained amino acids, such as serine, threonine, cysteine, methionine, and alanine, which can all be metabolized to pyruvate and thereby lactate. In this context, it may also be that the lactate shuttle in this case is not unidirectional and that RGCs may also metabolically provide Müller cells with lactate. In line with this, lactate has recently been shown to be metabolized in Müller cells [20,40], and it has also been proposed that other cells of the retina, such as photoreceptor cells, may facilitate the Müller cells with lactate $[40,50]$. Future studies with co-cultures of Müller cells and RGCs will elucidate mechanisms of lactate shuttle in the inner retina. Nevertheless, it can be speculated that RGCs may re-use their own pool of lactate or additional lactate released from Müller cells to 
the extracellular environment. In summary, we are the first to show that RGCs actually metabolize lactate and perhaps even prefer lactate metabolism for energy production, since the addition of unlabeled glucose did not have any effect on the total labeling in metabolic intermediates. This novel finding challenges previous assumptions of the use of lactate to spare glucose for neurons $[49,51]$, since RGCs are rather utilizing lactate than glucose as an energy substrate. However, it may be different for other neuronal cells of the retina. In this context, we have previously revealed that Müller cells are able to maintain their glycogen deposits over time in the presence of lactate [20], thereby potentially saving glucose as glycogen for other neighboring neurons of the retina. Regardless, preferable lactate consumption in the RGCs correlates nicely with an increase in ATP levels, thereby linking lactate metabolism with increased survival of RGCs. These findings differed from the study performed by Winkler et al. [21] in which ATP content of RGC-5 cells remained unaltered in response to $10 \mathrm{mM}$ of lactate in the media. The contradicting findings can be explained by the nature of RGC-5 cells, which have been shown to possess mice photoreceptor characteristics instead of the presumed RGC $[52,53]$. Thus, the use of primary murine RGCs in this study is of great importance. In our case, the presence of extracellular lactate protected the RGCs from dying of glucose deprivation, identifying a potential lactate-mediated neuroprotection of the RGCs through increased metabolism and ATP production. Our study may suggest that compromised lactate-facilitated neuroprotection may potentially be involved in the development of inner retinal diseases, in which the RGCs are dying. One of the most predominant inner retinal diseases is glaucoma, and a recent study revealed that patients with normal tension glaucoma had lower systemic blood lactate levels compared with age-matched healthy controls [54]. This supports the idea of a potential involvement of lactate in retinal neurodegeneration, which may consequently alter visual perception.

In conclusion, the present study revealed that high concentrations of extracellular lactate are crucial for RGC survival during sparse glucose supply. Albeit, future studies are necessary to explore the beneficial effects of lactate on neuronal survival in ex vivo and in vivo models of retinal neurodegeneration.

\section{Acknowledgments}

The authors thank laboratory technician Charlotte Taul Brændstrup for her skillful assistance to the study. The study was supported by the Michaelsen Foundation, The Velux Foundation, Fight for Sight Denmark, and The Hartmann Brothers Foundation. Special thanks to PhD student Evy Lefevere and
Professor Lieve Moons, Research Group Neural Circuit Development and Regeneration, KU Leuven, Belgium, for the protocol for retinal explants.

Conflicts of Interest: The authors declare no conflict of interest.

Received 22 December 2018;
Received in revised form 27 February 2019;
Accepted 5 March 2019

Available online 13 March 2019

Keywords:

retinal ganglion cells;

Müller cells;

lactate;

energy metabolism

Abbreviations used:

RGC, retinal ganglion cell; TPP, tissue culture plate; LDH, lactate dehydrogenase; PK, pyruvate kinase.

\section{References}

[1] A.T. Broman, H.A. Quigley, S.K. West, J. Katz, B. Munoz, K. Bandeen-Roche, et al., Estimating the rate of progressive visual field damage in those with open-angle glaucoma, from cross-sectional data, Invest. Ophthalmol. Vis. Sci. 49 (2008) 66-76, https://doi.org/10.1167/iovs.07-0866.

[2] J.M. Kim, H. Kyung, S.H. Shim, P. Azarbod, J. Caprioli, Location of initial visual field defects in glaucoma and their modes of deterioration, Invest. Ophthalmol. Vis. Sci. 56 (2015) 7956-7962, https://doi.org/10.1167/iovs.15-17297.

[3] E. Vecino, F.D. Rodriguez, N. Ruzafa, X. Pereiro, S.C. Sharma, Glia-neuron interactions in the mammalian retina, Prog. Retin. Eye Res. 51 (2016) 1-40, https://doi.org/10. 1016/j.preteyeres.2015.06.003.

[4] A.K. Toft-Kehler, D.M. Skytt, M. Kolko, A perspective on the Müller cell-neuron metabolic partnership in the inner retina, Mol. Neurobiol. (2017), https://doi.org/10.1007/s12035-017-0760-7.

[5] R.S. Chong, K.R. Martin, Glial cell interactions and glaucoma, Curr. Opin. Ophthalmol. 26 (2015) 73-77, https://doi.org/ 10.1097/ICU.0000000000000125.

[6] A.K. Toft-Kehler, D.M. Skytt, A. Svare, E. Lefevere, I. Van Hove, L. Moons, et al., Mitochondrial function in Müller cellsdoes it matter? Mitochondrion. (2017), https://doi.org/10.1016/ j.mito.2017.02.002.

[7] A. Bringmann, I. landiev, T. Pannicke, A. Wurm, M. Hollborn, P. Wiedemann, et al., Cellular signaling and factors involved in Müller cell gliosis: neuroprotective and detrimental effects, Prog. Retin. Eye Res. 28 (2009) 423-451, https://doi.org/10. 1016/j.preteyeres.2009.07.001.

[8] D.M. Skytt, A.K. Toft-Kehler, C.T. Brændstrup, S. Cejvanovic, I.S. Gurubaran, L.H. Bergersen, et al., Glianeuron interactions in the retina can be studied in cocultures of Müller cells and retinal ganglion cells, Biomed. Res. Int. (2016) 1-10, https://doi.org/10.1155/2016/1087647.

[9] A. Kawasaki, Y. Otori, C. Barnstable, Müller cell protection of rat retinal ganglion cells from glutamate and nitric oxide neurotoxicity, Invest. Ophthalmol. Vis. Sci. 41 (2000) 3444-3450. 
[10] K. Kashiwagi, Y. lizuka, M. Araie, Y. Suzuki, S. Tsukahara, Effects of retinal glial cells on isolated rat retinal ganglion cells, Invest. Ophthalmol. Vis. Sci. 42 (2001) 2686-2694.

[11] N. Ruzafa, E. Vecino, Effect of Müller cells on the survival and neuritogenesis in retinal ganglion cells, Arch. Soc. Esp. Oftalmol. 90 (2015) 522-526, https://doi.org/10.1016/j.oftal. 2015.03.009.

[12] A. Matteucci, L. Gaddini, M. Villa, M. Varano, M. Parravano, V. Monteleone, et al., Neuroprotection by rat Müller glia against high glucose-induced neurodegeneration through a mechanism involving ERK1/2 activation, Exp. Eye Res. 125 (2014) 20-29, https://doi.org/10.1016/j.exer.2014.05. 011.

[13] A. Schurr, R.S. Payne, J.J. Miller, B.M. Rigor, Brain lactate is an obligatory aerobic energy substrate for functional recovery after hypoxia: further in vitro validation, J. Neurochem. 69 (1997) 423-426.

[14] A. Schurr, R.S. Payne, J.J. Miller, B.M. Rigor, Brain lactate, not glucose, fuels the recovery of synaptic function from hypoxia upon reoxygenation: an in vitro study, Brain Res. 744 (1997) 105-111.

[15] A. Schurr, R.S. Payne, J.J. Miller, B.M. Rigor, Glia are the main source of lactate utilized by neurons for recovery of function posthypoxia, Brain Res. 774 (1997) 221-224.

[16] G. van Hall, M. Strømstad, P. Rasmussen, O. Jans, M. Zaar, C. Gam, et al., Blood lactate is an important energy source for the human brain, J. Cereb. Blood Flow Metab. 29 (2009) 1121-1129, https://doi.org/10.1038/jcbfm.2009.35.

[17] F. Boumezbeur, K.F. Petersen, G.W. Cline, G.F. Mason, K.L. Behar, G.I. Shulman, et al., The contribution of blood lactate to brain energy metabolism in humans measured by dynamic $13 \mathrm{C}$ nuclear magnetic resonance spectroscopy, J. Neurosci. 30 (2010) 13983-13991, https://doi.org/10.1523/JNEUROSCI. 2040-10.2010.

[18] H.S. Waagepetersen, I.J. Bakken, O.M. Larsson, U. Sonnewald, A. Schousboe, Comparison of lactate and glucose metabolism in cultured neocortical neurons and astrocytes using 13C-NMR spectroscopy, Dev. Neurosci. 20 (1998) 310-320.

[19] M.T. Wyss, R. Jolivet, A. Buck, P.J. Magistretti, B. Weber, In vivo evidence for lactate as a neuronal energy source, J. Neurosci. 31 (2011) 7477-7485, https://doi.org/10.1523/JNEUROSCI.041511.2011.

[20] R. Vohra, B.I. Aldana, D.M. Skytt, K. Freude, H. Waagepetersen, L.H. Bergersen, et al., Essential roles of lactate in Müller cell survival and function, Mol. Neurobiol. (2018), https://doi.org/10.1007/s12035-018-1056-2.

[21] B.S. Winkler, C.A. Starnes, M.W. Sauer, Z. Firouzgan, S.-C. Chen, Cultured retinal neuronal cells and Müller cells both show net production of lactate, Neurochem. Int. 45 (2004) 311-320, https://doi.org/10.1016/j.neuint.2003.08.017.

[22] B.S. Winkler, M.W. Sauer, C.A. Starnes, Modulation of the Pasteur effect in retinal cells: implications for understanding compensatory metabolic mechanisms, Exp. Eye Res. 76 (2003) 715-723.

[23] C.L. Poitry-Yamate, S. Poitry, M. Tsacopoulos, Lactate released by Müller glial cells is metabolized by photoreceptors from mammalian retina, J. Neurosci. 15 (1995) 5179-5191.

[24] A.J. Adler, R.E. Southwick, Distribution of glucose and lactate in the interphotoreceptor matrix, Ophthalmic Res. 24 (1992) 243-252.

[25] B.A. Berkowitz, N. Bansal, C.A. Wilson, Non-invasive measurement of steady-state vitreous lactate concentration, NMR Biomed. 7 (1994) 263-268.
[26] L. Wang, P. Törnquist, A. Bill, Glucose metabolism in pig outer retina in light and darkness, Acta Physiol. Scand. 160 (1997) 75-81, https://doi.org/10.1046/j.1365-201X.1997. 00030.x.

[27] S.K. Ng, J.P.M. Wood, G. Chidlow, G. Han, T. Kittipassorn, D.J. Peet, et al., Cancer-like metabolism of the mammalian retina, Clin. Exp. Ophthalmol. 43 (2015) 367-376, https://doi. org/10.1111/ceo.12462.

[28] A. Suzuki, S.A. Stern, O. Bozdagi, G.W. Huntley, R.H. Walker, P.J. Magistretti, et al., Astrocyte-neuron lactate transport is required for long-term memory formation, Cell. 144 (2011) 810-823, https://doi.org/10.1016/j.cell.2011.02.018.

[29] E.L. Cureton, R.O. Kwan, K.C. Dozier, J. Sadjadi, J.D. Pal, G. P. Victorino, A different view of lactate in trauma patients: protecting the injured brain, J. Surg. Res. 159 (2010) 468-473, https://doi.org/10.1016/j.jss.2009.04.020.

[30] A.C. Rice, R. Zsoldos, T. Chen, M.S. Wilson, B. Alessandri, R.J. Hamm, et al., Lactate administration attenuates cognitive deficits following traumatic brain injury, Brain Res. 928 (2002) 156-159.

[31] U. Pattamatta, Z. McPherson, A. White, A mouse retinal explant model for use in studying neuroprotection in glaucoma, Exp. Eye Res. 151 (2016) 38-44, https://doi.org/ 10.1016/j.exer.2016.07.010.

[32] N.D. Bull, T.V. Johnson, G. Welsapar, N.W. DeKorver, S.I. Tomarev, K.R. Martin, Use of an adult rat retinal explant model for screening of potential retinal ganglion cell neuroprotective therapies, Invest. Ophthalmol. Vis. Sci. 52 (2011) 3309-3320, https://doi.org/10.1167/iovs.10-6873.

[33] B.I. Aldana, Y. Zhang, M.F. Lihme, L.K. Bak, J.E. Nielsen, B. Holst, et al., Characterization of energy and neurotransmitter metabolism in cortical glutamatergic neurons derived from human induced pluripotent stem cells: a novel approach to study metabolism in human neurons, Neurochem. Int. 106 (2017) 48-61, https://doi.org/10.1016/j.neuint.2017.02.010.

[34] T.P. Mawhinney, R.S. Robinett, A. Atalay, M.A. Madson, Analysis of amino acids as their tert.-butyldimethylsilyl derivatives by gas-liquid chromatography and mass spectrometry, J. Chromatogr. 358 (1986) 231-242.

[35] K. Biemann, Mass spectrometry, Annu. Rev. Biochem. 32 (1963) 755-780, https://doi.org/10.1146/annurev.bi.32. 070163.003543.

[36] O. Warburg, On the origin of cancer cells, Science. 123 (1956) 309-314.

[37] L.H. Cohen, W.K. Noell, Glucose catabolism of rabbit retina before and after development of visual function, J. Neurochem. 5 (1960) 253-276.

[38] H.A. Krebs, The Pasteur effect and the relations between respiration and fermentation, Essays Biochem. 8 (1972) $1-34$.

[39] A. Ames, Y.Y. Li, E.C. Heher, C.R. Kimble, Energy metabolism of rabbit retina as related to function: high cost of $\mathrm{Na}^{+}$transport, J. Neurosci. 12 (1992) 840-853.

[40] K.J. Lindsay, J. Du, S.R. Sloat, L. Contreras, J.D. Linton, S.J. Turner, et al., Pyruvate kinase and aspartate-glutamate carrier distributions reveal key metabolic links between neurons and glia in retina, Proc. Natl. Acad. Sci. U. S. A. 111 (2014) 15579-15584, https://doi.org/10.1073/pnas. 1412441111.

[41] R. Vohra, I.S. Gurubaran, U. Henriksen, L.H. Bergersen, L.J. Rasmussen, C. Desler, et al., Disturbed mitochondrial function restricts glutamate uptake in the human Müller glia cell line, MIO-M1, Mitochondrion. (2017)https://doi.org/10. 1016/j.mito.2017.02.003. 
[42] A.K. Toft-Kehler, I.S. Gurubaran, C. Desler, L.J. Rasmussen, D.M. Skytt, M. Kolko, Oxidative stress-induced dysfunction of Müller cells during starvation, Invest. Ophthalmol. Vis. Sci. 57 (2016) 2721-2728, https://doi.org/10.1167/iovs.16-19275.

[43] I. Sussman, M. Erecińska, D.F. Wilson, Regulation of cellular energy metabolism: the Crabtree effect, Biochim. Biophys. Acta 591 (1980) 209-223.

[44] G. Chidlow, J.P.M. Wood, M. Graham, N.N. Osborne, Expression of monocarboxylate transporters in rat ocular tissues, Am. J. Physiol. Cell Physiol. 288 (2005) C416-C428, https://doi.org/10.1152/ajpcell.00037.2004.

[45] P.J. Magistretti, L. Pellerin, Regulation by neurotransmitters of glial energy metabolism, Adv. Exp. Med. Biol. 429 (1997) 137-143.

[46] P.J. Magistretti, L. Pellerin, D.L. Rothman, R.G. Shulman, Energy on demand, Science. 283 (1999) 496-497.

[47] P.J. Magistretti, I. Allaman, Lactate in the brain: from metabolic end-product to signalling molecule, Nat. Rev. Neurosci. (2018), https://doi.org/10.1038/nrn.2018.19.

[48] V. Carelli, F.N. Ross-Cisneros, A.A. Sadun, Mitochondrial dysfunction as a cause of optic neuropathies, Prog. Retin. Eye Res. 23 (2004) 53-89, https://doi.org/10.1016/j. preteyeres.2003.10.003.
[49] G.A. Dienel, Brain lactate metabolism: the discoveries and the controversies, J. Cereb. Blood Flow Metab. 32 (2012) 1107-1138, https://doi.org/10.1038/jcbfm.2011.175.

[50] J.B. Hurley, K.J. Lindsay, J. Du, Glucose, lactate, and shuttling of metabolites in vertebrate retinas, J. Neurosci. Res. 93 (2015) 1079-1092, https://doi.org/10.1002/jnr.23583.

[51] P. Proia, C.M. Di Liegro, G. Schiera, A. Fricano, I. Di Liegro, Lactate as a metabolite and a regulator in the central nervous system, Int. J. Mol. Sci. 17 (2016), https://doi.org/10.3390/ ijms 17091450 .

[52] N.J. Van Bergen, J.P.M. Wood, G. Chidlow, I.A. Trounce, R. J. Casson, W.-K. Ju, et al., Recharacterization of the RGC-5 retinal ganglion cell line, Invest. Ophthalmol. Vis. Sci. 50 (2009) 4267-4272, https://doi.org/10.1167/iovs.09-3484.

[53] J.P.M. Wood, G. Chidlow, T. Tran, J.G. Crowston, R.J. Casson, A comparison of differentiation protocols for RGC-5 cells, Invest. Ophthalmol. Vis. Sci. 51 (2010) 3774-3783, https://doi.org/10.1167/iovs.09-4305.

[54] R. Vohra, L.M. Dalgaard, J. Vibaek, M.A. Langbøl, L.H. Bergersen, N.V. Olsen, et al., Potential metabolic markers in glaucoma and their regulation in response to hypoxia, Acta Ophthalmol. (2019), https://doi.org/10.1111/aos.14021. 